\title{
Assessing Sediment Toxicity from Navigational Pools of the Upper Mississippi River Using a 28-Day Hyalella azteca Test
}

\author{
N. E. Kemble, E. L. Brunson, T. J. Canfield,* F. J. Dwyer, C. G. Ingersoll \\ Environmental and Contaminants Research Center, United States Geological Survey, 4200 New Haven Road, Columbia, Missouri 65201, USA
}

Received: 6 July 1997/Accepted: 3 January 1998

\begin{abstract}
To assess the extent of sediment contamination in the Upper Mississippi River (UMR) system after the flood of 1993, sediment samples were collected from 24 of the 26 navigational pools in the river and from one site in the Saint Croix River in the summer of 1994. Whole-sediment tests were conducted with the amphipod Hyalella azteca for 28 days measuring the effects on survival, growth, and sexual maturation. Amphipod survival was significantly reduced in only one sediment (13B) relative to the control and reference sediments. Body length of amphipods was significantly reduced relative to the control and reference sediments in only one sample (26C). Sexual maturation was not significantly reduced in any treatment when compared to the control and reference sediments. No significant correlations were observed between survival, growth, and maturation to either the physical or chemical characteristics of the sediment samples from the river. When highly reliable effect range medians (ERMs) were used to evaluate sediment chemistry, 47 of $49(96 \%)$ of the samples were correctly classified as nontoxic. These results indicate that sediment samples from the Upper Mississippi River are relatively uncontaminated compared to other areas of known contamination in the United States.
\end{abstract}

The Mississippi River is the largest river system in the United States. Because of its location, the river receives contaminant inputs from a variety of industrialized and agricultural sources. The Upper Mississippi River (UMR), the stretch of river upstream from the confluence with the Ohio River at Cairo, IL, contains a series of 26 navigational pools created by a lock and dam system from St. Louis, MO to Minneapolis, MN (Rada $e t$ al. 1990) (Figure 1). These navigational pools are shallow, lake-like areas that trap and store large quantities ( 1 to $4 \mathrm{~cm} / \mathrm{yr}$ ) of primarily fine-grained sediments during normal river flows (McHenry et al. 1984; Nielsen et al. 1984). Dredging activities, commercial navigation, recreational boating, and natural resuspension processes can result in the remobilization of these

* Present address: Robert S. Kerr Environmental Research Laboratory, United States Environmental Protection Agency, 919 Kerr Research Drive, Ada, Oklahoma 74820, USA

Correspondence to: N. E. Kemble sediments. Concern about the resuspension and transport of these sediments and the contaminants associated with them arose after the flood of 1993 (Moody and Meade 1995; Moody 1996).

The United States Geological Survey (USGS) has been monitoring the transport and degradation of pollutants in the UMR since the fall of 1987 (Moody and Meade 1995). Studies have monitored concentrations of contaminants in fish (Hora 1984; Wiener et al. 1984), invertebrates (Beauvais et al. 1995; Steingraeber and Wiener 1995), sediments (Bailey and Rada 1984; Wiener et al. 1984; Rada et al. 1990; Frazier et al. 1996; Ingersoll et al. 1998), or a combination of the three (Peddicord et al. 1980; Boyer 1984) in select pools in the UMR. However, no information was available on contaminant concentrations and toxicity in sediment samples throughout the entire pool system of the UMR.

Four studies were conducted to assess the nature and extent of sediment contamination in the navigational pools of the UMR: (1) contaminant concentrations were measured in sediments before and after the flood of 1993 (Moody 1996); (2) whole-sediment toxicity tests were conducted (present study); (3) whole-sediment bioaccumulation tests were conducted (Brunson et al. 1998); and (4) benthic-community structure was evaluated (Canfield et al. 1998). A companion study by Winger and Lasier (1998) evaluated sediment toxicity in select locations of the lower Mississippi River. Sediment samples for the present study were collected from June 11 th to July 5th, 1994 from Pool 1 (near Minneapolis, MN) to Pool 26 (near St. Louis, MO) of the UMR system (Figure 1). The objective of the present study was to assess the toxicity of sediments from navigational pools of the UMR system using 28-day toxicity tests with the amphipod Hyalella azteca, measuring for potential effects on survival, growth, or sexual maturation.

\section{Materials and Methods}

\section{Sample Collection, Handling, and Storage}

Differential Global Positioning System (GPS), using a local reference, was used to locate sampling stations (accuracy $\pm 0.005^{\circ}$ latitude or longitude) in the upper pools ( 1 to 14 ) and the Saint Croix River. A differential GPS using the navigational beacon near St. Louis, MO (accuracy $\pm 0.001^{\circ}$ latitude or longitude), was used as the reference to locate 


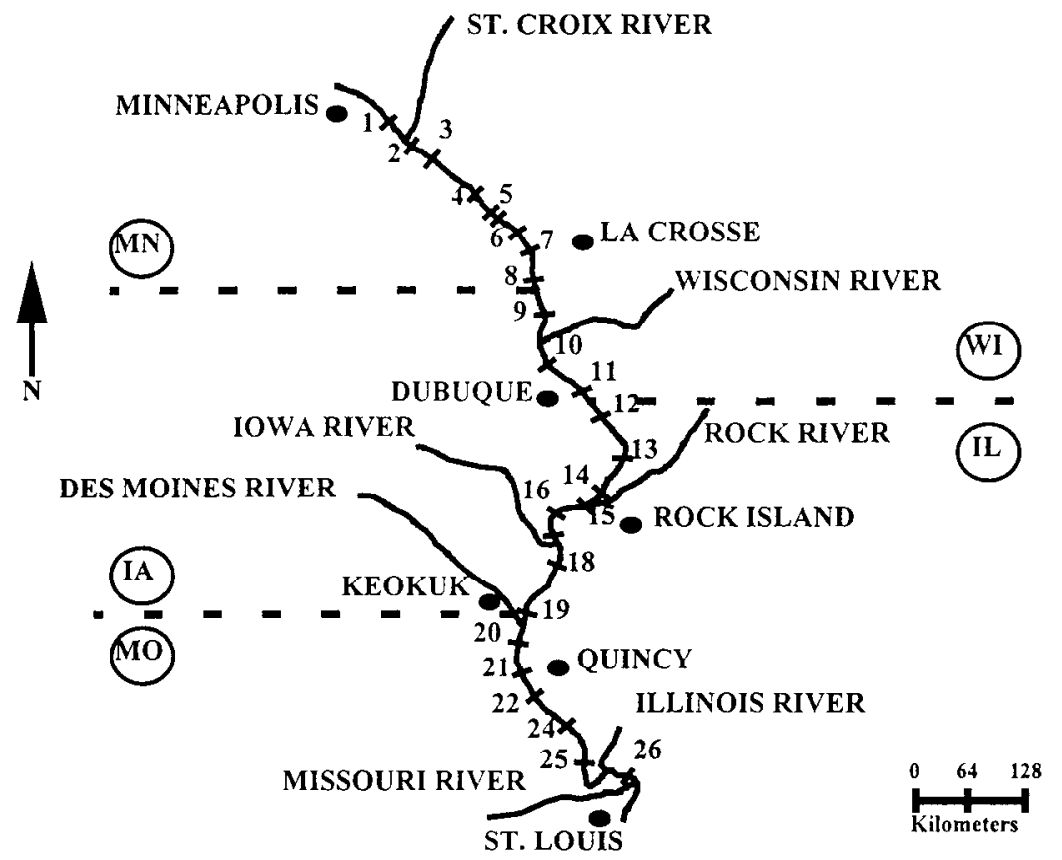

Fig. 1. Map of the Upper Mississippi River (UMR) from Minneapolis, MN to Saint Luuis, MO sampling stations in the lower pools (15 to 26). A 3.5-L composite sediment sample was collected from each of the 26 navigational pools (pool samples designated as "B" samples; Moody 1996). These composite samples of surface (upper $10 \mathrm{~cm}$ ) sediments were collected using a van Veen grab from 15 to 20 stations along one to five transects (typically three to five stations/transect) from the downstream one-third of each navigation pool (except Pool 17) in the UMR and from one sitc in the Saint Croix River (SC) just upstream from its confluence with the Mississippi River in Wisconsin (Figure 1) (Moody 1996). Samples were not collected from the main navigation channel, which was assumed to contain coarser sediment deposited for a short period of time. A 2-L subsample of the 3.5-L samples for toxicity testing and physical and chemical characterization was removed and placed in a 2-L high density polyethylene (HDPE) screw-topped container. Samples were stored in a cooler at $4^{\circ} \mathrm{C}$ for 7 to 14 days on the research ship Acadiana, then shipped on ice to the Environmental and Contaminants Research Cenler (ECRC) in Columbia, MO. Two 125-ml subsamples from each B sample were collected at the start of the toxicity tests for physical (grain size and total organic carbon [TOC]) and chemical (organic and metal) characterization.

A second composite sediment sample was also collected from each pool at one station on one of the transects (station samples designated as " $\mathrm{C}$ " samples). The individual stations ( $\mathrm{C}$ samples) were selected based on historical chemistry data and the potential for the collection of large numbers of oligochaetes for bioaccumulation evaluations (Brunson et al. 1998). Station sediment samples (C samples) for toxicity and bioaccumulation (Brunson et al. 1998) testing were collected with a Ponar grab (529 $\mathrm{cm}^{2}$ area). Each C sample was a composite sample collected from the upper 6 to $10 \mathrm{~cm}$ of the sediment surface within a $5-\mathrm{m}$ radius area. A total of $35-80 \mathrm{~L}$ of sediment was collected from each $\mathrm{C}$ station. The sediment was then placed into a 120-L HDPE drum and homogenized on ship with a stainless steel auger on a hand-held power drill. Subsamples of these C samples were taken for: (1) laboratory toxicity and laboratory bioaccumulation testing (10 L), (2) physical characterization $(250 \mathrm{ml})$ and chemical characterization ( 250 $\mathrm{ml}$ for organics and $250 \mathrm{ml}$ for metals), and (3) benthic invertebrate assessment (Canfield et al. 1998) (2 L). The remaining C sample was then sieved and native oligochaetes were collected for bioaccumulation analyses (Brunson et al. 1998). Sediment samples were stored in a cooler on the ship at $4^{\circ} \mathrm{C}$ for 7 to 14 days, then shipped on ice to the ECRC in Columbia, MO. Once at the ECRC, sediment samples were stored in the dark at $4^{\circ} \mathrm{C}$ until the start of the study. The control sediment (Florissant soil; FLOR) used in the toxicity tests was a fine silt- and clay-particle size soil collected near St. Louis, MO. This control sediment has been used in previous studies (Kemble et al. 1994; Ingersoll et al. 1996).

\section{Culturing of Test Organisms}

Amphipods were mass cultured at $23^{\circ} \mathrm{C}$ with a luminance of about 800 lux in $80-\mathrm{L}$ glass aquariums containing $50 \mathrm{~L}$ of ECRC well water (hardness $283 \mathrm{mg} / \mathrm{L}$ as $\mathrm{CaCO}_{3}$, alkalinity 255 as $\mathrm{CaCO}_{3}, \mathrm{pH} 7.8$ ) with a nylon, coiled-web material (3M Corp., Saint Paul, MN) as substrates (Tomasovic et al. 1995). Known-age amphipods were isolated by placing mixed-aged adults in a \#35 US Standard size sieve $(5-\mathrm{mm}$ mesh) inside a pan containing about $2 \mathrm{~cm}$ of well water. After $24 \mathrm{~h}$, well water was sprinkled through the sieve, flushing $<24$-h-old neonates into the pan below. Isolated amphipods were then placed into glass-lift chambers (Cleveland et al. 1991) for 10 days before the exposure began. Isolated amphipods were fed maple leaves and ground Tetra$\min ^{\otimes}$ ad lib until the start of the sediment exposures.

\section{Toxicity Tests}

Sediment Preparation: Sediment samples were rehomogenized in the laboratory using either a plastic spoon (for the B samples) or a hand-held power drill with a stainless steel auger (for the $C$ samples). Subsamples were then collected for: (1) pore-water preparation, (2) physical and chemical characterizations, (3) toxicity testing, and (4) bioaccumulation testing C samples only (Brunson et al. 1998).

Water Quality: About $170 \mathrm{ml}$ of pore water was isolated from each sample by centrifugation at $4^{\circ} \mathrm{C}$ for $15 \mathrm{~min}$ at $5,200 \mathrm{rpm}(7000 \mathrm{~g})$. Immediately after pore water was isolated, the following water quality characteristics were measured: sulfide, dissolved oxygen, $\mathrm{pH}$, alkalinity, hardness, temperature, conductivity, and total ammonia using procedures described in Kemble et al. (1994) and Kemble et al. (1997). 
Mean characteristics of pore-water quality (ranges in parentheses) are as follows: $\mathrm{pH}, 7.45$ (6.69-8.17); alkalinity, 505 (244-852) $\mathrm{mg} / \mathrm{L}$; hardness, 504 (148-852) $\mathrm{mg} / \mathrm{L}$; dissolved oxygen, 5.04 (1.50-9.35) $\mathrm{mg} / \mathrm{L}$; conductivity, $906(380-1680) \mu \mathrm{s} / \mathrm{cm} @ 25^{\circ} \mathrm{C}$; total ammonia, $5.320(1.210-22.700) \mathrm{mg} / \mathrm{L}$; unionized ammonia, 0.007 (0.000-0.025) $\mathrm{mg} / \mathrm{L}$; total sulfide, $0.055(0.000-0.569) \mathrm{mg} / \mathrm{L}$; and hydrogen sulfide, $0.023(0.000-0.569) \mathrm{mg} / \mathrm{L}$ (Kemble et al. 1997).

The following parameters were measured in overlying test water on Day -1 (the day before amphipods were placed into the beakers) and at the end of each toxicity test: dissolved oxygen, temperature, conductivity, $\mathrm{pH}$, alkalinity, total hardness, and total ammonia. Methods used to characterize overlying water quality in the whole-sediment tests were similar to the methods described for characterization of pore water. Dissolved oxygen, $\mathrm{pH}$, and conductivity were also measured weekly. Temperature in the water baths holding the exposure beakers was measured daily. Overlying water $\mathrm{pH}$, alkalinity, total hardness, conductivity, and total ammonia measurements were similar among all stations, the control, and in flowing test water (Kemble et al. 1997). Dissolved oxygen measurements were at or above acceptable levels ( $>40 \%$ of saturation; ASTM 1998) in all treatments throughout the study (Kemble et al. 1997). Means (ranges in parentheses) of uverlying water quality of each parameter are as follows: $\mathrm{pH}, 8.07$ (7.58-8.72); alkalinity, 87 (59-151) mg/L; hardness, 128 (111-160) mg/L; dissolved oxygen, 6.70 (5.84-7.53) mg/L; conductivity, 392 (359-428) $\mu \mathrm{s} / \mathrm{cm} @$ $25^{\circ} \mathrm{C}$; total ammonia, $0.416(0.090-1.520) \mathrm{mg} / \mathrm{L}$; and unionized ammonia, 0.003 (0.000-0.012) $\mathrm{mg} / \mathrm{L}$ (Kemble et al. 1997).

Toxicity Tests: All sediment tests were started within three months of sample collection from the field. Due to the number of samples collected, half (i.e., half of the sites) were randomly selected for the initial testing. The second set of sediment samples was tested after completion of testing of the first set. Sediment samples for the toxicity tests were homogenized the day before animals were added to exposure beakers (Day -1 ), using procedures described above.

Toxicity tests were conducted with $H$. azteca for 28 days. Effects of exposure to sediments on survival, length, and sexual maturation of amphipods were measured (US EPA 1994; ASTM 1998). Each 300-ml beaker contained $100 \mathrm{ml}$ of sediment and $150 \mathrm{ml}$ of overlying water. The photoperiod was 16:8 h (light:dark) at a light intensity of about 500 lux. Four replicate beakers/sample were placed in a ventilated water bath maintained at $23^{\circ} \mathrm{C}$. Each beaker received 1.0 volume additions/ day of overlying water starting on Day -1 (Zumwalt et al. 1994). The overlying water used in the sediment toxicity exposures was a reconstituted moderately hard water (hardness $95 \mathrm{mg} / \mathrm{L}$ as $\mathrm{CaCO}_{3}$, alkalinity $65-70 \mathrm{mg} / \mathrm{L}$ as $\mathrm{CaCO}_{3}, \mathrm{pH} \mathrm{8.0-8.3)} \mathrm{(US} \mathrm{EPA} \mathrm{1994).} \mathrm{One}$ diluter cycle delivered $50 \mathrm{ml}$ of water to each beaker (diluters cycled every $8 \mathrm{~h} \pm 15 \mathrm{~min}$ ). Amphipods were acclimated to the test water over $6 \mathrm{~h}$ before exposures began by sequentially transferring animals at $2 \mathrm{~h}$ intervals into 50:50 and 25:75 mixtures of well water:test water, and then into $100 \%$ test water. Tests were started on Day 0 by placing 10 amphipods (10-11 -days old) into each beaker. The water surface in each beaker was checked for floating organisms $15 \mathrm{~min}$ after organisms were placed in the beaker. Amphipods in each beaker were fed $3 \mathrm{mg}$ of Purina Rabbit Pellets ${ }^{\circledR}$ in a water suspension three times a week for the first 7 days of the exposure, and $6 \mathrm{mg}$ three times a week for the last 21 days of the exposure. If excessive mold ( $\geq 60 \%$ sediment surface) was observed on the sediment surface of any of the beakers in a treatment, feeding was withheld from all of the beakers for that treatment (the number of feedings withheld ranged from 0 to 5 depending on the treatment) (US EPA 1994; ASTM 1998). Beakers were observed daily for the presence of animals, signs of animal activity (i.e., burrowing), and to monitor test conditions (i.e., water clarity).

Amphipods were retrieved from each beaker at the end of exposures using procedures described in Kemble et al. (1994). Surviving organism were combined into a scintillation vial and preserved in $8 \%$ sugar formalin for later measurement of length, and sexual maturation. A Zeiss ${ }^{\circledR}$ Interactive Digital Analysis System in combination with a
Zeiss SV8 stereomicroscope at a magnification of $25 \times$ was used to measure amphipods following methods described in Kemble $e t$ al. (1994). The number of adult males and females in each beaker was determined after the 28-day amphipod exposure (mature male amphipods were distinguished by the presence of an enlarged second gnathopod; Kemble et al. 1994).

\section{Chemical and Physical Characterization of Sediments}

Acid-Volatile Sulfides (AVS) and Simultaneously Extractable Metals (SEM): Subsamples of sediments were measured for acid-volatile sulfides (AVS) and simultaneously extractable metals (SEM) immediately after homogenization. Station samples (C samples) were collected on the boat and stored at $4^{\circ} \mathrm{C}$ until shipment to the laboratory. Pool samples (B samples) were collected in the laboratory immediately after sediment homogenization before the start of toxicity tests. Concentrations of AVS in sediment samples were determined using a silver/ sulfide electrode following methods described in Brumbaugh et al. (1994). Concentrations of SEM were determined using atomic spectroscopy following methods described in Brumbaugh et al. (1994).

Percentage recoveries for inorganics from both blank and sediment extracts averaged $96 \%$. The average range was from a low of $78 \%$ for antimony (spiked as sodium sulfide) in the sediment extract to a high of $110 \%$ for $7 \mathrm{n}$ in the sediment extract. The average duplicate coefficient of variation was $1.7 \%$ ( 6 compounds, $\mathrm{n}=2$ ). Average duplicate coefficient of variation ranged from $0.2 \%$ for both $\mathrm{Pb}$ samples to $5.1 \%$ for $\mathrm{S}$ in one of the duplicate samples.

Organochlorine Pesticides (OCPs), Polychlorinated Biphenyls (PCBs), and Aliphatic and Polycyclic Aromatic Hydrocarbons (PAHs): Sediment samples (C samples) were prepared for the analyses of organochlorine pesticides (OCPs), polychlorinated biphenyls (PCBs), and aliphatic and polycyclic aromatic hydrocarbons (PAHs) by extracting 20 $\mathrm{g}$ of sedinient with acetone, followed by petroleum ether. A final acetone/petroleum ether extraction was done and the extracts combined, centrifuged, and transferred to a separatory funnel containing sufficient water to facilitate partitioning of residues into petroleum ether portion. The petroleum ether was washed twice with water and concentrated by Kuderna-Danish to appropriate volume.

Organochlorine determination was conducted by transferring an aliquot of concentrated extract to a 1.6-g Florisil mini-column topped with $1.6 \mathrm{~g}$ sodium sulfate. Residues were eluted from the column in two elution fractions. The first fraction consisted of $12 \mathrm{ml}$ of hexane followed by $12 \mathrm{ml}$ of $1 \%$ methanol in hexane; the second fraction consisted of an additional $24 \mathrm{ml}$ of $1 \%$ methanol in hexane. Quantification of residues in the two Florisil fractions and three silicic acid fractions was performed using a packed or megabore column and electron capture gas chromatography.

Hydrocarbon determination was conducted by transferring a second aliquot of the concentrated extract to a $20 \mathrm{~g} 1 \%$ deactivated silica gel column, topped with $5 \mathrm{~g}$ neutral alumina. Aliphatic and polynuclear aromatic hydrocarbon residues were fractioned by eluting aliphatics from the column with $100 \mathrm{ml}$ petroleum ether (fraction 1) followed by elution of aromatics using, $100 \mathrm{ml} 40 \%$ methylene chloride $/ 60 \%$ petroleum ether, followed by $50 \mathrm{ml}$ methylene chloride (combined eluates, fraction 2). Quantification of fraction 1 by capillary column, flame ionization gas chromatography was performed once the fraction was concentrated to appropriate volume. The silica gel (fraction 2) containing aromatic hydrocarbons was concentrated, reconstituted in methylene chloride, and quantified by gas chromatography and mass spectrometry.

Average percent spike recovery for 18 OCPs was $103 \%(n=2)$. The smallest average spike recovery was $68 \%$ for $\mathrm{HCB}$ while $0, \mathrm{p}^{\prime}$-DDE had the greatest average spike recovery $(120 \%)$. Individual OCP concentrations were below minimum detection limits, so duplicate analyses were not evaluated. Average percent spike recovery for PAH compounds was 
98\% (29 compounds, $\mathrm{n}=2$ ). Naphthalene $(84 \%)$ had the smallest average percent recovery while fluoranthene had the greatest average spike recovery (110\%). The average duplicate coefficient of variation was $12.6 \%$ ( 13 compounds, $n=2$ ). Average duplicate coefficient of variation ranged from $0 \%$ for multiple PAHs in both duplicatc samples to $61 \%$ for benzo(a)pyrene in one of the samples.

Methods for the analyses of the B samples, detection limits and quality control are described in Moody (1996). Quality control of B sediment samples analyzed for PAHs included: (1) estimates of accuracy determined from the standard deviation of the percent recovery of deuterated compounds added to the extracts and calculated based on absolute area counts and external calibration; and (2) precision, based on the relative standard deviation of the absolute area of multiple analyses of a surrogate compound (Moody 1996). A list of all the PAHs and OCPs analyzed for in both sets of sediment samples (B and C) are listed in Kemble et al. 1997.

\section{Physical Characterization of Sediments}

Physical characterization of sediments included: (1) percentage water (Kemble et al. 1993); (2) particle size using a hydrometer (Foth et al. 1982; Gee and Bauder 1986; Kemble et al. 1993); and (3) total organic carbon using a coulometric titration (Cahill et al. 1987; Kemble et al. 1993). All physical characterizations included analysis of duplicate samples. Differences in percentage water for duplicate samples ranged from $0 \%$ in treatments $2 \mathrm{~B}, 7 \mathrm{~B}, 13 \mathrm{C}, 14 \mathrm{~B}$, and $18 \mathrm{~B}$ to $7 \%$ in treatment 10C. Duplicate samples of control sediment, sucrose standards, and blanks were analyzed when determining sediment total organic. Precision and accuracy of the coulometric technique used was tested against National Bureau of Standards and Standard Reference Materials (NBS-SRM) with an error of less than $0.03 \%$ of the excepted values (Cahill et al. 1987). Differences between duplicates ranged from $0 \%$ in treatments $3 \mathrm{~B}, 11 \mathrm{~B}, 12 \mathrm{~B}, 13 \mathrm{C}, 14 \mathrm{C}, 15 \mathrm{C}, 18 \mathrm{C}, 20 \mathrm{C}, 22 \mathrm{C}, 22 \mathrm{~B}, 24 \mathrm{C}$, and $26 \mathrm{C}$ to $0.9 \%$ in treatments $5 \mathrm{C}, 9 \mathrm{C}$, and $26 \mathrm{~B}$.

\section{Data Analysis and Statistics}

Toxicity Tests: Beforc statistical analyses werc performed, data for survival and maturation were arcsin transformed. Comparisons of mean survival and percentage sexual maturation were made using a one-way nested analysis of variance (ANOVA) with mean separation by Fisher's protected least significant difference test at alpha $=0.05$ (Snedecor and Cochran 1982). Data for length had a normal distribution and were not transformed before statistical analysis. Comparison of mean body length was made using a one-way ANOVA with mean separation by Fisher's protected least significant difference test at alpha $=0.05$ (Snedecor and Cochran 1982). A sample was designated as toxic when survival, growth, or sexual maturation were significantly reduced relative to the control and reference sediments. Sediments from Pools 6 and 11 were chosen as reference sediments based on low concentrations of contaminants. Simple linear regression was used to compare physical and chemical sediment characteristics to amphipod survival, length, or sexual maturation. All statistical analyses were performed with SAS programs (SAS 1994).

Effects Range Median: Chemistry concentrations and toxicity endpoints were evaluated using 28-day $H$. azteca effect range medians (ERMs) reported by Ingersoll et al. (1996) and Smith et al. (1996). An ERM is defined as the concentration of a chemical in sediment above which effects are frequently or always observed or predicted for most species (Long et al. 1995). The total number of individual ERMs exceeded with each sample was plotted against the mean ERM quotient (the concentration of each chemical in the sediment sample divided by the ERM for that chemical), similar to the toxic unit described by
Table 1. Results of the Upper Mississippi River sediment tests with Hyalella azteca ${ }^{\text {a }}$

\begin{tabular}{|c|c|c|c|}
\hline Sample & Survival (\%) & $\begin{array}{l}\text { I ength } \\
(\mathrm{mm})^{\mathrm{b}}\end{array}$ & $\begin{array}{l}\text { Mature } \\
\text { Males (\%) }\end{array}$ \\
\hline \multicolumn{4}{|l|}{ First Set of Samples } \\
\hline Control & $80.0(4.08)$ & $3.39(0.16)$ & $36.7(8.91)$ \\
\hline $1 \mathrm{~B}$ & $92.5(4.79)$ & $3.66(0.11)$ & $39.1(5.71)$ \\
\hline $1 \mathrm{C}$ & $65.0(5.00)$ & $3.17(0.11)$ & $16.9(6.90)$ \\
\hline $3 \mathrm{~B}$ & $95.0(5.00)$ & $4.27(0.08)$ & $44.9(8.43)$ \\
\hline $5 B$ & $80.0(7.07)$ & $4.23(0.06)$ & $44.8(10.30)$ \\
\hline $5 \mathrm{C}$ & $80.0(7.07)$ & $4.06(0.10)$ & $21.6(4.23)$ \\
\hline $8 B$ & $97.5(2.50)$ & $3.69(0.09)$ & $40.5(7.72)$ \\
\hline $8 \mathrm{C}$ & $92.5(2.50)$ & $4.09(0.11)$ & $32.3(7.68)$ \\
\hline $10 \mathrm{~B}$ & $92.5(7.50)$ & $4.28(0.09)$ & $39.5(18.49)$ \\
\hline $10 \mathrm{C}$ & $72.5(13.15)$ & $3.86(0.08)$ & $34.4(6.88)$ \\
\hline 11B (reference) & $87.5(2.50)$ & $4.31(0.07)$ & $43.3(11.57)$ \\
\hline $11 \mathrm{C}$ (reference) & $57.5(8.54)$ & $3.61(0.07)$ & $32.8(15.79)$ \\
\hline $12 \mathrm{~B}$ & $72.5(9.46)$ & $3.48(0.07)$ & $34.5(3.00)$ \\
\hline $12 \mathrm{C}$ & $85.0(6.45)$ & $3.78(0.07)$ & $32.4(5.85)$ \\
\hline $15 B$ & $90.0(4.08)$ & $3.74(0.08)$ & $51.3(11.46)$ \\
\hline $15 \mathrm{C}$ & $72.5(2.50)$ & $3.59(0.09)$ & $34.0(8.64)$ \\
\hline $16 \mathrm{~B}$ & $70.0(9.13)$ & $3.72(0.08)$ & $40.6(6.56)$ \\
\hline $16 \mathrm{C}$ & $90.0(7.07)$ & $3.83(0.07)$ & $30.0(10.13)$ \\
\hline $21 \mathrm{~B}$ & $95.0(2.89)$ & $3.46(0.06)$ & $52.2(6.08)$ \\
\hline $21 \mathrm{C}$ & $87.5(4.79)$ & $3.87(0.09)$ & $51.4(5.29)$ \\
\hline $25 B$ & $62.5(13.15)$ & $3.60(0.11)$ & $23.8(10.51)$ \\
\hline $25 \mathrm{C}$ & $62.5(15.48)$ & $3.63(0.08)$ & $29.6(8.34)$ \\
\hline $26 \mathrm{~B}$ & $92.5(4.79)$ & $3.51(0.09)$ & $42.0(6.82)$ \\
\hline $26 \mathrm{C}$ & $90.0(7.07)$ & $2.88(0.01)^{*}$ & $48.8(11.30)$ \\
\hline \multicolumn{4}{|c|}{ Second Set of Samples } \\
\hline Control & $97.5(2.50)$ & $2.59(0.08)$ & $5.9(3.42)$ \\
\hline $2 \mathrm{~B}$ & $75.0(8.66)$ & $4.07(0.11)$ & $31.3(6.25)$ \\
\hline $2 \mathrm{C}$ & $75.0(10.41)$ & $3.47(0.10)$ & $43.8(8.08)$ \\
\hline $4 B$ & $85.0(6.45)$ & $3.39(0.10)$ & $36.7(13.72)$ \\
\hline $4 \mathrm{C}$ & $62.5(21.75)$ & $3.35(0.09)$ & $12.1(5.22)$ \\
\hline 6B (reference) & $67.5(17.02)$ & $3.53(0.09)$ & $26.9(9.21)$ \\
\hline $6 \mathrm{C}$ (reference) & $82.5(2.50)$ & $4.08(0.10)$ & $54.5(2.97)$ \\
\hline $7 \mathrm{~B}$ & $100.0(0.00)$ & $3.66(0.06)$ & $42.5(10.31)$ \\
\hline $7 \mathrm{C}$ & $95.0(2.89)$ & $3.70(0.07)$ & $35.5(3.41)$ \\
\hline $9 B$ & $75.0(10.41)$ & $3.72(0.09)$ & $43.6(6.47)$ \\
\hline $9 \mathrm{C}$ & $67.5(13.77)$ & $3.65(0.08)$ & $32.8(11.24)$ \\
\hline $13 \mathrm{~B}$ & $32.5(7.50)^{*}$ & $3.87(0.19)$ & $18.8(11.97)$ \\
\hline $13 \mathrm{C}$ & $47.5(10.31)$ & $3.56(0.11)$ & $50.0(9.64)$ \\
\hline $14 \mathrm{~B}$ & $65.0(5.00)$ & $3.85(0.12)$ & $31.6(7.36)$ \\
\hline $14 \mathrm{C}$ & $47.5(7.50)$ & $3.50(0.12)$ & $43.8(15.72)$ \\
\hline $18 \mathrm{~B}$ & $77.5(7.50)$ & $3.57(0.12)$ & $50.0(18.89)$ \\
\hline $18 \mathrm{C}$ & $72.5(17.97)$ & $3.52(0.09)$ & $20.8(7.50)$ \\
\hline $19 \mathrm{~B}$ & $85.0(6.45)$ & $3.31(0.07)$ & $40.2(7.50)$ \\
\hline $19 \mathrm{C}$ & $72.5(7.50)$ & $3.44(0.07)$ & $32.3(15.91)$ \\
\hline $20 \mathrm{~B}$ & $82.5(8.54)$ & $3.43(0.08)$ & $11.9(5.14)$ \\
\hline $20 \mathrm{C}$ & $95.0(2.89)$ & $3.30(0.06)$ & $27.2(10.74)$ \\
\hline $22 B$ & $85.0(6.45)$ & $3.79(0.10)$ & $24.4(3.00)$ \\
\hline $22 \mathrm{C}$ & $52.5(10.31)$ & $3.64(0.11)$ & $39.9(14.20)$ \\
\hline $24 \mathrm{~B}$ & $87.5(2.50)$ & $3.61(0.08)$ & $34.4(4.65)$ \\
\hline $24 \mathrm{C}$ & $60.0(8.16)$ & $3.78(0.12)$ & $66.9(14.19)$ \\
\hline $\mathrm{SCB}$ & $75.0(10.41)$ & $3.42(0.10)$ & $11.9(7.89)$ \\
\hline $\mathrm{SCC}$ & $90.0(4.08)$ & $3.03(0.06)$ & $31.7(5.60)$ \\
\hline
\end{tabular}

a Means (standard error of the means in parentheses) within a column and within a set of sample are significantly different $(p<0.05 ; n=4)$ from the control and reference sediment and are designated with an asterisk

b Starting body length of amphipods in the first set of samples was 1.05 $\mathrm{mm}(0.02 \mathrm{SE}, \mathrm{n}=11)$ and was $1.17 \mathrm{~mm}(0.04 \mathrm{SE}, \mathrm{n}=10)$ in the second set of samples 
Canfield et al. (1996), Ingersoll et al. (1996), and Swartz and Di Toro (1997). We chose to evaluate sediment toxicity relative to nine of the most reliable ERMs that correctly classified $>70 \%$ of the samples in Ingersoll et al. (1996). These nine individual ERMs tended to minimize Type I (false positive) and Type II (false negative) errors relative to other sediment quality guidelines reported by Ingersoll et al. (1996). Due to insufficient chemistry data for chromium and total PCBs, only seven of the nine individual ERMs were used in this evaluation. These ERMs included: cadmium, lead, nickel, zinc, chrysene, benzo(a)pyrene, and benzo(g,h,i)perylene.

\section{Results and Discussion}

\section{Toxicity Tests}

Survival of amphipods was significantly reduced relative to the control and reference sediments only in the $13 \mathrm{~B}$ treatment (Table 1). Body length of amphipods was significantly reduced relative to the control and reference sediments in only the $26 \mathrm{C}$ treatment (Table 1). Sexual maturation was not significantly reduced in any treatments when compared to the control and reference sediments. Pairs of amphipods were observed in amplexus in the control, 1B, 2B, 5B, 6C, 8B, 8C, 9B, 10B, 11B, $14 \mathrm{C}, 15 \mathrm{~B}, 18 \mathrm{C}, 24 \mathrm{~B}, 24 \mathrm{C}$, and $26 \mathrm{~B}$ treatments, and gravid females were observed in the control, 11B, 16C , and 24B treatments.

Although significant differences in survival of amphipods relative to the control and reference sediments were only observed in sample 13B, there was a relatively wide range in survival among the treatments. For example survival was below $70 \%$ in 13 of the 51 treatments (Table 1). Survival of amphipods in the control was acceptable ( $\geq 80 \%$ ) (US EPA 1994; ASTM 1998), however, survival in two of the four reference treatments (11C and 6B) was below $80 \%$. Subsequent studies have found that the reconstituted water described in US EPA (1994) that was used to conduct this study does not consistently support adequate survival and growth of $\mathrm{H}$. azteca in 28-day exposures (McNulty 1995; Kemble et al. 1998). Ingersoll et al. (1998) retested sediment samples $4 \mathrm{C}, 11 \mathrm{C}, 14 \mathrm{C}$, and $24 \mathrm{C}$ using well water as an overlying water and observed a mean survival of $>90 \%$ in all of the samples with no substantial effects on growth, or reproduction of $H$. azteca. Survival of amphipods in these same sediments ranged from $48 \%$ to $63 \%$ in the present study (Table 1). Similarly, Benoit et al. (1997) tested station samples $(7 \mathrm{C}, 9 \mathrm{C}, 13 \mathrm{C}, 22 \mathrm{C}$, and $24 \mathrm{C}$ ) in chronic toxicity tests with midge Chironomus tentans using a natural overlying water and did not observe effects on survival, growth, emergence, or reproduction of midges. Ingersoll et al. (1998) recommended conducting long-term sediment toxicity tests with $H$. azteca using a natural source of overlying water until an acceptable reconstituted water has been developed.

\section{Physical and Chemical Characteristics of Sediments}

Physical characteristics of sediment samples are listed in Table 2. Kemble et al. (1997) summarizes chemical analyses of these sediment samples. [These data are also available through our Internet home page (http://www.ecrc.cr.usgs.gov/pubs/umr.html).] Sediment organic carbon content ranged from $0.2 \%$ for the sediment samples from Stations $6 \mathrm{~B}$ and $20 \mathrm{~B}$ to $5.2 \%$ for Station
Table 2. Physical and chemical characteristics of sediments from the Upper Mississippi River at the start of whole-sediment tests ${ }^{\mathrm{a}}$

\begin{tabular}{|c|c|c|c|c|c|c|c|}
\hline \multirow[b]{2}{*}{ Sample } & \multirow{2}{*}{$\begin{array}{l}\text { Total } \\
\text { Organic } \\
\text { Carbon } \\
(\%)\end{array}$} & \multirow{2}{*}{$\begin{array}{l}\text { Solids } \\
(\%)\end{array}$} & \multicolumn{3}{|c|}{ Particle Size (\%) } & \multirow{2}{*}{$\begin{array}{l}\text { Mean } \\
\text { Sum } \\
\text { ERM } \\
\text { Quotient }\end{array}$} & \multirow[b]{2}{*}{ Sediment Class } \\
\hline & & & Sand & Clay & Silt & & \\
\hline 1B & 0.3 & 76.5 & 88.6 & 9.3 & 2.1 & 0.17 & Sand/loamy sand \\
\hline 1C & 0.5 & 77.9 & 88.8 & 10.1 & 1.1 & 0.11 & Sand/loamy sand \\
\hline $2 \mathrm{~B}$ & 3.6 & 61.3 & 53.5 & 25.5 & 21.0 & 0.24 & Sandy clay loam \\
\hline $2 \mathrm{C}$ & 3.3 & 45.0 & 15.4 & 43.1 & 41.5 & 0.23 & Silty clay \\
\hline $3 \mathrm{~B}$ & 2.7 & 53.2 & 27.5 & 23.5 & 49.0 & 0.14 & Loam \\
\hline $4 B$ & 4.8 & 26.2 & 11.6 & 49.0 & 39.5 & 0.24 & Clay \\
\hline $4 C$ & 5.0 & 20.8 & 33.4 & 39.8 & 26.9 & 0.37 & Clay loam \\
\hline $5 B$ & 1.6 & 61.5 & 53.6 & 19.4 & 26.4 & 0.03 & Sandy loam \\
\hline $5 C$ & 5.1 & 27.7 & 31.6 & 31.0 & 37.5 & 0.12 & Clay loam \\
\hline $6 \mathrm{~B}$ & 0.2 & 77.3 & 84.6 & 12.4 & 3.0 & 0.02 & Loamy sand \\
\hline $6 \mathrm{C}$ & 0.7 & 70.2 & 78.1 & 13.6 & 8.3 & 0.04 & Sandy loam \\
\hline $7 \mathrm{~B}$ & 1.0 & 47.7 & 17.1 & 32.1 & 50.7 & 0.04 & Silty clay loam \\
\hline $7 \mathrm{C}$ & 2.3 & 62.1 & 56.5 & 16.8 & 26.7 & 0.09 & Sandy loam \\
\hline $8 B$ & 1.3 & 57.5 & 58.0 & 18.8 & 23.2 & 0.03 & Sandy loam \\
\hline $8 \mathrm{C}$ & 2.2 & 55.5 & 11.5 & 37.0 & 51.5 & 0.07 & Silty clay loam \\
\hline $9 \mathrm{~B}$ & 2.0 & 56.3 & 27.6 & 21.5 & 50.9 & 0.07 & Silt loam \\
\hline $9 \mathrm{C}$ & 2.9 & 48.0 & 9.3 & 29.4 & 61.3 & 0.09 & Silty clay loam \\
\hline $10 \mathrm{~B}$ & 1.2 & 55.2 & 59.6 & 36.9 & 3.5 & 0.04 & Sandy clay \\
\hline $10 \mathrm{C}$ & 5.2 & 20.7 & 24.3 & 41.7 & 34.0 & 0.13 & Clay \\
\hline $11 \mathrm{~B}$ & 1.3 & 59.8 & 46.1 & 18.8 & 35.1 & 0.04 & Loam \\
\hline $11 \mathrm{C}$ & 1.8 & 64.7 & 46.2 & 21.6 & 31.3 & 0.04 & Loam \\
\hline $12 B$ & 2.0 & 54.2 & 20.0 & 20.9 & 59.1 & 0.11 & Silt loam \\
\hline $12 \mathrm{C}$ & 2.3 & 54.9 & 15.3 & 21.4 & 63.3 & 0.12 & Silt loam \\
\hline $13 \mathrm{~B}$ & 1.8 & 65.4 & 33.2 & 23.1 & 43.7 & 0.03 & Luam \\
\hline $13 \mathrm{C}$ & 1.8 & 52.1 & 14.6 & 22.0 & 63.4 & 0.07 & Silt loam \\
\hline $14 \mathrm{~B}$ & 0.6 & 35.8 & 4.0 & 42.5 & 53.5 & 0.03 & Silty clay \\
\hline $14 \mathrm{C}$ & 3.0 & 61.0 & 58.7 & 18.4 & 22.9 & 0.10 & Sandy loam \\
\hline $15 \mathrm{~B}$ & 1.4 & 46.9 & 0.0 & 23.0 & 77.0 & 0.07 & Silt loam \\
\hline $15 \mathrm{C}$ & 1.9 & 59.0 & 41.5 & 20.5 & 38.0 & 0.08 & Loam \\
\hline $16 \mathrm{~B}$ & 1.2 & 67.0 & 53.7 & 18.9 & 27.4 & 0.06 & Sandy loam \\
\hline $16 \mathrm{C}$ & 2.8 & 67.4 & 51.3 & 21.9 & 26.8 & 0.11 & Sandy clay loam \\
\hline $18 \mathrm{~B}$ & 0.7 & 69.1 & 64.0 & 19.5 & 16.5 & 0.05 & Sandy loam \\
\hline $18 \mathrm{C}$ & 1.7 & 62.6 & 21.8 & 23.8 & 54.5 & 0.08 & Silt loam \\
\hline $19 \mathrm{~B}$ & 1.9 & 54.9 & 33.8 & 29.4 & 36.9 & 0.07 & Clay loam \\
\hline $19 \mathrm{C}$ & 2.3 & 49.2 & 7.6 & 34.0 & 58.4 & 0.09 & Silty clay loam \\
\hline $20 \mathrm{~B}$ & 0.2 & 84.1 & 81.4 & 11.7 & 6.8 & 0.03 & Loamy sand \\
\hline $20 \mathrm{C}$ & 0.8 & 73.5 & 52.1 & 22.0 & 26.0 & 0.06 & Sandy clay loam \\
\hline $21 \mathrm{~B}$ & 0.5 & 69.9 & 64.0 & 23.5 & 12.5 & 0.05 & Sandy clay loam \\
\hline $21 \mathrm{C}$ & 1.1 & 59.0 & 44.4 & 25.8 & 29.8 & 0.04 & Loam \\
\hline $22 \mathrm{~B}$ & 0.5 & 73.3 & 62.1 & 23.4 & 14.5 & 0.04 & Sandy clay loam \\
\hline $22 \mathrm{C}$ & 2.4 & 44.4 & 0.3 & 40.3 & 59.4 & 0.08 & Silt clay loam \\
\hline $24 \mathrm{~B}$ & 0.7 & 74.6 & 57.5 & 23.0 & 19.5 & 0.03 & Sandy clay loam \\
\hline $24 \mathrm{C}$ & 1.7 & 57.1 & 30.7 & 22.0 & 47.4 & 0.07 & Loam \\
\hline $25 \mathrm{~B}$ & 1.4 & 63.3 & 33.2 & 30.7 & 36.1 & 0.05 & Clay loam \\
\hline $25 \mathrm{C}$ & 1.1 & 56.2 & 16.6 & 28.0 & 55.4 & 0.05 & Silty clay loam \\
\hline $26 \mathrm{~B}$ & 2.0 & 54.5 & 24.1 & 33.5 & 42.5 & 0.07 & Clay loam \\
\hline $26 \mathrm{C}$ & 0.7 & 72.6 & 43.5 & 27.0 & 29.5 & 0.06 & Clay loam \\
\hline SCB & 3.0 & 34.0 & 53.4 & 24.8 & 21.9 & 0.13 & Sandy clay loam \\
\hline SCC & 4.3 & 26.6 & 36.1 & 25.5 & 38.5 & 0.17 & Loam \\
\hline FLORB & 1.2 & 32.0 & 12.3 & 26.5 & 61.3 & 0.15 & Silty clay loam \\
\hline FLORC & 1.2 & 32.0 & 12.3 & 26.5 & 61.3 & 0.15 & Silty clay loam \\
\hline
\end{tabular}

a The sum ERM-quotient was also calculated for each sample

10C. Organic carbon content in the control sediment was $1.2 \%$. Percentage solids ranged from $21 \%$ in the sediment sample from stations $4 \mathrm{C}$ and $10 \mathrm{C}$ to $84 \%$ for the sediment sample from Station 20B. Classification of the sediment samples for grain size varied from pool to pool (i.e., loam [11C], sandy-loam [8B], silty-clay-loam [25C and $22 \mathrm{C}]$ ) while the control sedi- 

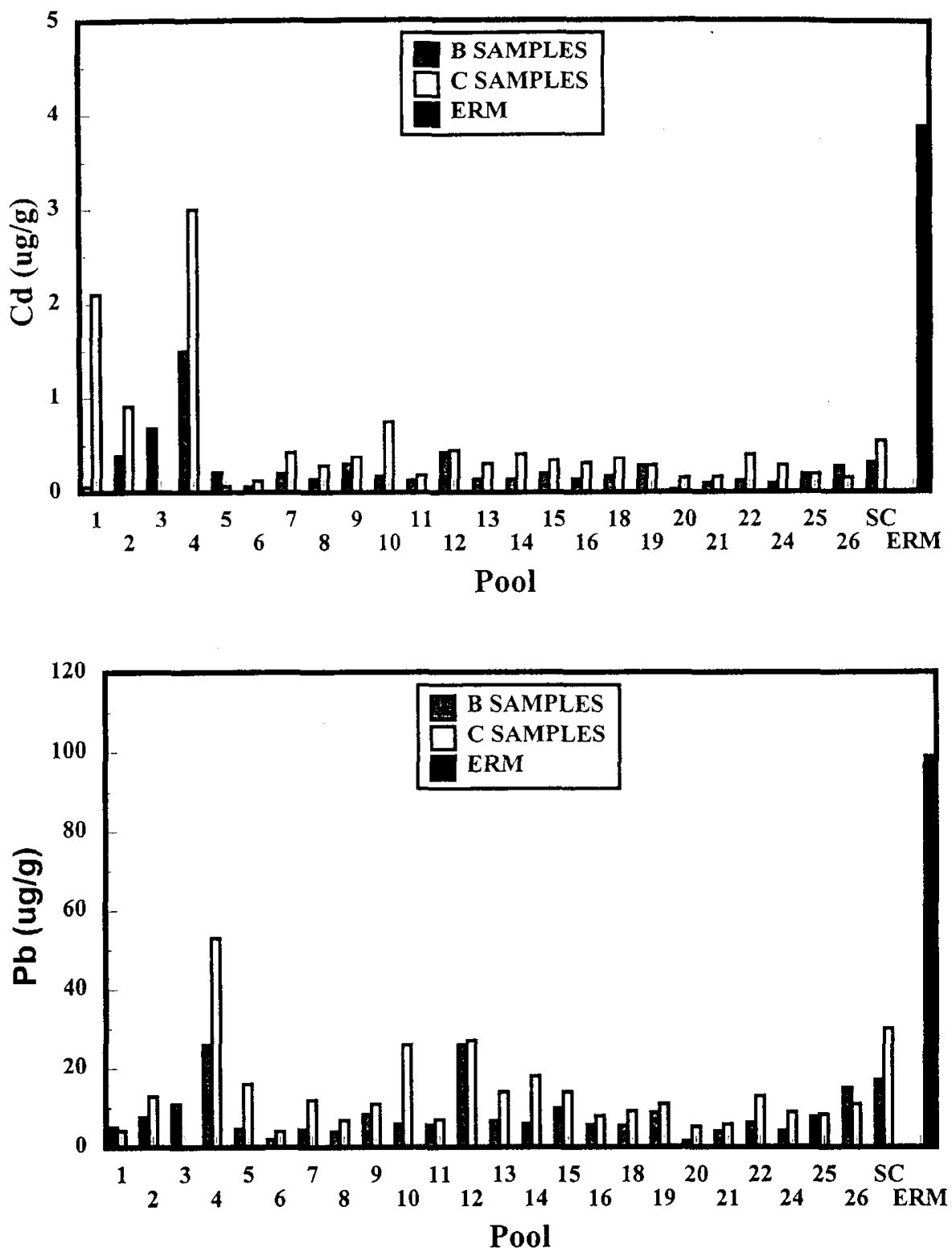

Fig. 2. Concentrations of simultaneously extracted metal (SEM) Cd in UMR sediment samples compared to a effect range median (ERM) for $\mathrm{Cd}$
Fig. 3. Concentrations of SEM Pb in UMR sediment samples compared to a ERM for $\mathrm{Pb}$ ment was a silty-clay-loam (Table 2 ). Acid volatile sulfide levels ranged from $0.005 \mu$ moles/g in the $1 \mathrm{C}$ sample to 63.0 $\mu$ moles/g in the $10 \mathrm{C}$ sample (Table 2 ).

Sediment from sample $4 \mathrm{C}$ had the highest concentrations of extractable SEM Cd, $\mathrm{Cu}, \mathrm{Ni}$, and $\mathrm{Pb}$. Sample $12 \mathrm{C}$ had the highest concentration of SEM Zn $(143 \mu \mathrm{g} / \mathrm{g})$ (Kemble et al. 1997). However, concentrations of SEM Cu and $\mathrm{Pb}$ were still below the ERMs reported by Ingersoll et al. (1996) (Figures 2 and 3). The sum SEM/AVS molar ratio in the present study was typically less than 1 (except the two samples from Pool 1). This indicates the concentration of divalent metals were probably not high enough to result in toxicity of the samples (Di Toro et al. 1990). Concentrations of SEM Cd, $\mathrm{Cu}, \mathrm{Ni}$, and $\mathrm{Pb}$ were highest in sediment samples from Pool 4C (Kemble et al. 1997).

Significant positive correlations were observed between SEM metals versus TOC $(\mathrm{Cu}>\mathrm{Zn}>\mathrm{Cd}>\mathrm{Pb}>\mathrm{Ni})$. SEM metals versus percentage clay $(\mathrm{Zn}>\mathrm{Ni}>\mathrm{Pb}>\mathrm{Cu}>\mathrm{Cd}$ ) and between SEM metals versus percentage silt $(\mathrm{Ni}>\mathrm{Cu}>\mathrm{Pb}>\mathrm{Zn}>\mathrm{Cd})$ when tested by Spearman's rho coefficient of rank correlation (Kemble et al. 1997). The significant negative correlation with sand and the positive comelation with clay and silt indicates that metals were concentrated in the finer sediment particles.

Concentrations of OCPs were below detection limits $(0.01$ $\mu \mathrm{g} / \mathrm{g}$ ) in all of the $\mathrm{C}$ samples except the $2 \mathrm{C}$ and Saint Croix $\mathrm{C}$ samples, which had detectable concentrations of DDE and DDD (Kemble et al. 1997). Amphipod survival in the 2C sediment sample was $75 \%$. However, despite having concentrations that were similar for both chemicals, survival of amphipods in the Saint Croix C sample was $90 \%$. This indicates that the levels of DDE and DDD detected in these samples was not the cause of the lower survival observed in the $2 \mathrm{C}$ sediment sample. Concentrations of OCPs in the B samples were at or below detection limits for 10 of the 15 individual pesticides evaluated (Kemble et al. 1997). Concentrations for all five OCPs detected in the B samples were $\leq 0.079 \mu \mathrm{g} / \mathrm{g}$ dry weight and were below calculated ERMs (Smith et al. 1996; Kemble et al. 1997). 

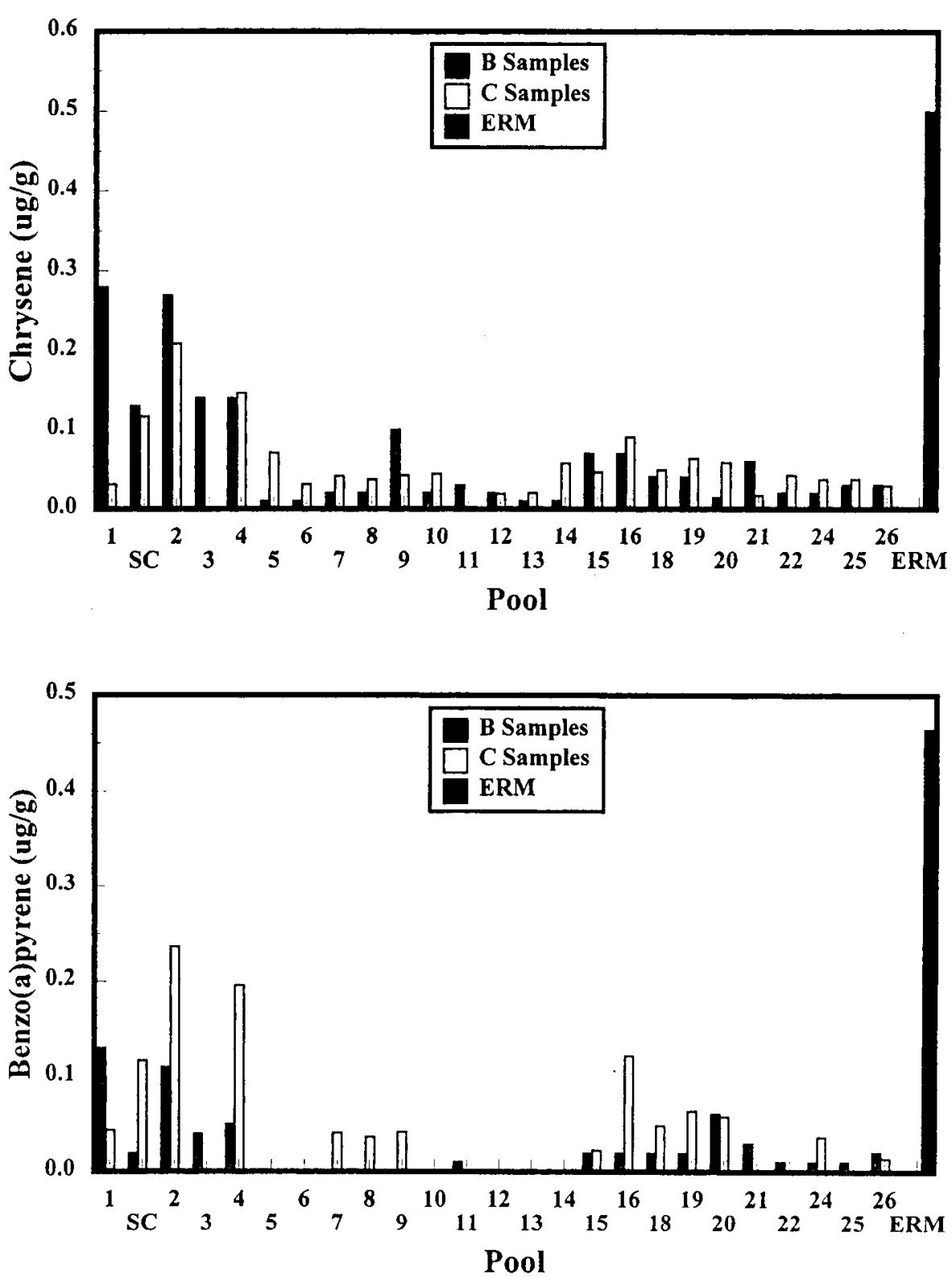

Fig. 4. Concentrations of chrysene in UMR sediment samples compared to an ERM for chrysene
Fig. 5. Concentrations of benzo(a)pyrene (BAP) in UMR sediment samples compared to an ERM for BAP
The highest concentrations of PAHs were observed at Pool 1 and were generally lower in the downstream pools. Concentrations of PAHs in river sediments exceeded the method lower limit of quantitation (MLLQ; $0.03 \mu \mathrm{g} / \mathrm{g}$ ) in at least one sediment sample for every PAH evaluated (except for 1-methylnaphthalene) (Kemble et al. 1997). Concentrations of four of the 11 PAHs exceeded at least one calculated ERM (Ingersoll et al. 1996) (Figures 4 and 5). Elevated PAH concentrations in sediment samples were associated with sediment collected from pools near Minneapolis, MN. Concentrations of PAHs below Pool 4 were similar in the remaining pools. Concentrations of fluoranthene exceeded the calculated ERM $(0.175 \mu \mathrm{g} / \mathrm{g})$ in nine of the sediment samples from the UMR. Amphipod survival in these samples was above $75 \%$ in all but one of the samples (Sample 4C, which had a survival of $63 \%$; Table 1 ). This would indicate that concentrations of fluoranthene in these samples had little or no effect on amphipod survival.

\section{Comparisons of Sediment Characteristics} to Toxicity Responses

Relationships of physical or chemical characteristics of sediments to toxicity were evaluated using rank correlation (Kemble et al. 1997). No significant correlations were observed between survival, growth, or maturation of amphipods and the measured physical or chemical characteristics of the sediment samples (Kemble et al. 1997). Additionally, no significant correlation was observed between the toxicity endpoints and concentrations of PAHs or OCPs normalized to total organic carbon concentrations (Kemble et al. 1997). Winger and Lasier (1998) did not observe toxicity in sediments from the lower Mississippi River in a companion study. Sediments from Pool 1 had the highest percent sand ( $>88 \%$ ), but amphipod length and maturation were not reduced with exposure to $1 \mathrm{~B}$ or $1 \mathrm{C}$ sediments relative to the control and reference sediments (Table 


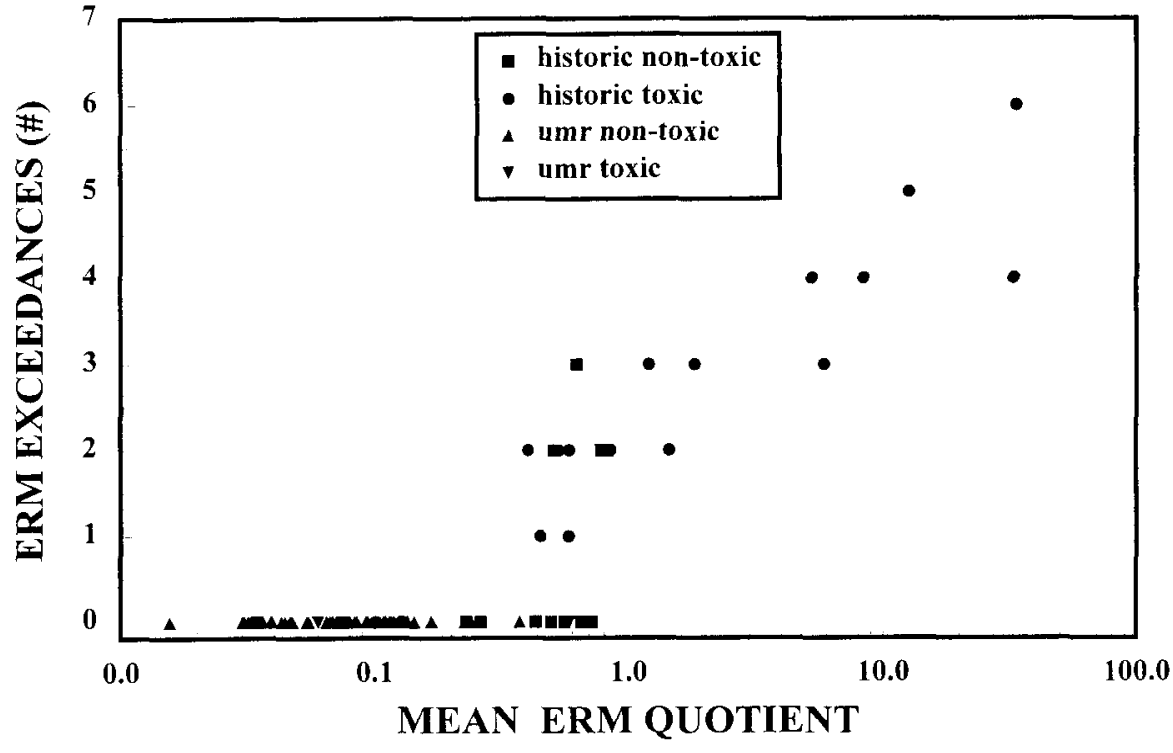

Fig. 6. Number of ERM exceedances for the seven highly reliable ERMs chemicals that correctly classified $70 \%$ of the samples compared to mean ERM toxic quotient for a historic database (Ingersoll et al. 1996) and for the present study
1). Similarly, the control sediment had the highest percent silt and clay relative to the other samples. Ingersoll and Nelson (1990), Kemble et al. (1994), and Ingersoll et al. (1998) also reported sediment particle size did not affect the survival or growth of $H$. azteca in 28-day sediment exposures.

None of the 49 sediment samples exceeded any of the highly reliable seven individual ERMs. Use of these seven ERMs correctly classified 47 of the $49(96 \%)$ sediment samples from the UMR as nontoxic. The two samples incorrectly classified were both type II errors (false negative; toxic sample that does not exceed an ERM). This again indicates that something other than contaminants or contaminants not measured were the cause of the variation in survival among the sediment treatments.

The prediction of sediment toxicity was also evaluated using a toxic quotient approach. A toxic quotient was calculated for each sample by first dividing the concentration of individual chemicals by their respective ERM, summing the individual values, and then dividing by the number of ERMs evaluated (Canfield et al. 1996; Ingersoll et al. 1996). In the present study, ERMs for the seven chemicals listed above were used to calculate a toxic quotient for each sample (Table 2). Figure 6 plots the relationship between the frequency of ERM exceedances and the mean ERM toxic quotient. In the present study, the mean ERM toxic quotient was $\leq 0.37$ and individual ERMs were not exceeded, indicating the sediment samples from the UMR were relatively noncontaminated compared to sediments from areas of known contamination in the United States (Kemble et al. 1994; Ingersoll et al. 1996).

\section{Summary}

Toxicity tests using amphipods identified only two of the 49 sediment samples from the Upper Mississippi River system as toxic (a significant reduction in survival, growth, or sexual maturation compared to the control and reference sediments). However, there was a relatively wide range in survival among the treatments. The overlying water used in this test was the reconstituted water described in US EPA (1994), which McNulty
(1995) and Kemble et al. (1998) have demonstrated does not consistently support adequate survival of $H$. azteca in 28-day sediment exposures. Survival of amphipods and midge was $>90 \%$ in subsequent studies with sediments from the present study when natural water was used as the overlying test water (Benoit et al. 1997; Ingersoll et al. 1998). This would indicate that the reconstituted test water was a significant factor in the wide range of survival observed in the present study.

Effect range medians (ERMs) were used to evaluate the toxicity of contaminants associated with field-collected sediments. ERMs correctly classified $96 \%$ of the UMR sediment samples as nontoxic based on amphipod toxicity. The two samples incorrectly classified were type II errors (false negatives). Concentrations of contaminants in sediments from the UMR were typically 10 to 100 times less than concentrations of contaminants in sediments previously associated with toxicity (Kemble et al. 1994; Ingersoll et al. 1996). This would indicate that the sediment samples from the UMR were relatively noncontaminated compared to other areas of know contamination across the United States.

Acknowledgments. We would like to thank Linda Sappington for assistance on Quality Control and Quality Assurance and the following individuals for their input on the project: Eugene Greer, Doug Hardesty, Pam Haverland, Chris Henke, Ed Henry, Phil Lovely, John Moody, Shane Reussler, Julie Soltvedt, Jeff Steevens, Ron Walton, Dave Whites, Dave Zumwalt, the crew of the Acadiana (Craig LeBoeuf and Pat Marmande), and the laboratories providing chemical analysis of the sediment samples. Thanks to Dave Mount, James Fairchild, and Parley Winger and two anonymous reviewers for their helpful comments on the manuscript. We also thank Tom Armitage and Betsy Sutherland and the US EPA Office of Water for financial support. Reference to trade names or manufactures does not imply government endorsement of commercial products. This paper has been reviewed in accordance with US EPA policy.

\section{References}

American Society of Testing and Materials (ASTM) (1998) E 1706$95 \mathrm{~b}$. Standard guide for conducting sediment toxicity tests with 
freshwater invertebrates. ASTM 11.05 1998, Annual book of ASTM standards. American Society for Testing and Materials, Philadelphia, PA

Bailey PA, Rada RG (1984) Distribution and enrichment of trace metals $(\mathrm{Cd}, \mathrm{Cr}, \mathrm{Cu}, \mathrm{Ni}, \mathrm{Pb}, \mathrm{Zn})$ in bottom sediments of navigational pools 4 (Lake Pepin), 5, and 9 of the Upper Mississippi River. In: Wiener JG, Anderson RV, McConville DR (eds) Contaminants in the upper Mississippi River. Butterworth Publ., Boston, MA, pp 119-138

Beauvais SL, Wiener JG, Atchison GJ (1995) Cadmium and mercury in sediment and burrowing mayfly nymphs (Hexagenia) in the upper Mississippi River, USA. Arch Environ Contam Toxicol 28:178183

Benoit DA, Sibley PK, Jeunemann J, Ankley GT (1997) Chironomus tentans life cycle test: design and evaluation for use in assessing toxicity of contaminated sediments. Environ Toxicol Chem 16: $1165-1176$

Boyer HA (1984) Trace elements in water sediments and fish of the upper Mississippi River, Twin Cities metropolitan area. In: Wiener JG, Anderson RV, McConville DR (eds) Contaminants in the upper Mississippi River. Butterworth Publ, Boston, MA, pp 195-230

Brumbaugh WG, Ingersoll CG, Kemble NE, May TW, Zajicek JL (1994) Chemical characterization of sediments and pore water from the upper Clark Fork River and Milltown Reservoir, Montana. Environ Toxicol Chem 13:1971-1983

Brunson EL, Canfield TJ, Dwyer FJ, Ingersoll CG, Kemble NE (1998) Assessing bioaccumulation of contaminants from sediments of the upper Mississippi River using field-collected oligochaetes and laboratory-exposed Lumbriculus variegatus. Arch Environ Contam Toxicol 35:191-201

Cahill RA, Autrey AD, Anderson RV, Grubaugh JW (1987) Improved measurement of the organic carbon content of various river components. J Freshw Ecol 4:219-223

Canfield TJ, Dwyer FJ, Fairchild JF, Haverland PS, Ingersoll CG, Kemble NE, Mount DR, La Point TW, Burton GA, Swift MC (1996) Assessing contamination in Great Lake sediments using benthic invertebrate communities and the sediment quality triad approach. J Great Lakes Res 22:565-583

Canfield TJ, Brunson EL, Dwyer FJ, Ingersoll CG, Kemble NE (1998) Assessing sediments from the upper Mississippi River navigational pools using a benthic community evaluation and the sediment quality triad approach. Arch Environ Contanı Toxicol 35:202-212

Cleveland L. Little EE. Ingersoll CG, Wiedmeyer RH, Hunn JB (1991) Sensitivity of brook trout to low $\mathrm{pH}$, low calcium and elevated aluminum concentrations during laboratory pulse exposures. Aquat Toxicol 19:303-318

Di Toro DM, Mahony JH, Hansen DJ, Scott KJ, Hicks MB, Mayr SM, Redmond M (1990) Toxicity of cadmium in sediments: the role of acid volatile sulfides. Environ Toxicol Chem 9:1487-1502

Foth HD, Withee LV, Jacobs HS, Thien SJ (1982) Laboratory manual for introductory soil science. Brown Comp., Dubuque, IA, pp $13-26$

Frazier BE, Naimo TJ, Sandheinrich (1996) Temporal and vertical distribution of total ammonia nitrogen and un-ionized ammonia nitrogen in sediment pore water from the upper Mississippi River. Environ Toxicol Chem 15:92-99

Gee GW, Bauder JW (1986) Particle-size analysis. In: Klute A (ed) Methods of soil analysis. No. 9, Part 1, Agronomy Series. American Society of Agronomy, Madison, WI, pp 383-4l l

Hora ME (1984) Polychlorinated biphenyls (PCBs) in common carp (Cyprinus carpio) of the upper Mississippi. In: Wiener JG, Anderson RV, McConville DR (eds) Contaminants in the upper Mississippi River. Butterworth Publ., Boston, MA, pp 231-239

Ingersoll CG, Nelson MK (1990) Testing sediment toxicity with Hyalella azteca (Amphipoda) and Chironomus riparius (Diptera). In: Landis WG, van der Schalie WH (eds) Aquatic toxicology and risk assessment, Vol. 13. STP 1096, American Society for Testing and Materials, Philadelphia, PA, pp 93-109

Ingersoll CG, Haverland PS, Brunson EL, Canfield TJ, Dwyer FJ, Henke, CE, Kemble NE, Mount DR, Fox RG (1996) Calculation and evaluation of sediment effect concentration for the amphipod Hyalella azteca and the midge Chironomus riparius. J Great Lakes Res 22:602-623

Ingersoll CG, Brunson EL, Dwyer FJ, Hardesty DK, Kemble NE (1998) Use of sublethal endpoints in sediment toxicity tests with the amphipod Hyalella azteca. Environ Toxicol Chem (in press)

Kemble NE, Besser JM, Brumbaugh WG, Brunson EL, Canfield TJ, Coyle JJ, Dwyer FJ, Fairchild JF, Ingersoll CG, La Point TW, Meadows JC. Monda DP, Poulton BC, Woodward DF. Zajicek JL (1993) Sediment toxicology. In: Effects of metal-contaminated sediment, water, and diet on aquatic organisms. PB93-215952, final report, US Environmental Protection Agency, Helena, MT, pp 2-1-2-100

Kemble NE, Brumbaugh WG, Brunson EL, Dwyer FJ, Ingersoll CG, Monda DP, Woodward DF (1994) Toxicity of metal-contaminated sediments from the upper Clark Fork River, Montana to aquatic invertebrates and fish in laboratory exposures. Environ Toxicol Chem 13:1985-1997

Kemble NE, Brunson EL, Canfield TJ, Dwyer FJ, Ingersoll CG (1997) Evaluation of contamination in sediments collected from navigational ponls of the upper Mississippi River using a 28 day Hyalella azteca test. In: Dwyer FJ, Brunson EL, Canfield TJ, Ingersoll CG, Kemble NE (eds) An assessment of sediments from the upper Mississippi River. EPA 823-R-97-005, US Environmental Protection Agency, Washington, DC pp 1.1-1.65

Kemble NE, Dwyer FJ, Ingersoll CG (1998) Development of a formulated sediment for use in whole-sediment toxicity testing. Environ Toxicol Chem (in press)

Long ER, MacDonald DD, Smith SL, Calder FD (1995) Incidence of adverse biological effects within ranges of chemical concentrations in marine and estuarine sediments. Environ Manage 19: $81-97$

McHenry JR, Ritchie JC, Cooper CM, Verdon J (1984) Recent rates of sedimentation in the Mississippi River. In: Wiener JG. Anderson RV, McConville DR (eds) Contaminants in the upper Mississippi River. Butterworth Publ, Boston, MA, pp 67-98

McNulty EW (1995) Culturing and testing issues of Hyalella azteca in contannination assessments. MS thesis, Univ. Missouri, Columbia, $63 \mathrm{pp}$

Moody JA, Meade RH (1995) Hydrologic and sedimentologic data collected during three cruises on the Mississippi River and some of its tributaries from Minneapolis, Minnesota, to New Orleans, Louisiana, July 1991-May 1992. US Geological Survey Open-File Report 94-474

Moody JA (ed) (1996) Hydrologic and sedimentologic, and chemical data describing surficial bed sediments in the navigational polls of the upper Mississippi River after the flood of 1993. U.S. Geological Survey Open File Report 96-580

Nielsen DN, Rada RG, Smart MM (1984) Sediments of the upper Mississippi River: their sources, distribution, and characteristics. In: Wiener JG, Anderson RV, McConville DR (eds) Contaminants in the upper Mississippi River. Butterworth Publ., Boston, MA, pp $67-98$

Peddicord R, Tatem H, Gibson A, Pedron S (1980) Biological assessment of upper Mississippi River sediments. Miscellaneous Paper EL-80-5, US Army Engineer Waterways Experiment Station, CE, Vicksburg, MS

Rada RG, Wiener JG, Bailey PA, Powell DE (1990) Recent influxes of metals into Lake Pepin, a natural lake on the upper Mississippi River. Arch Environ Contam Toxicol 19:712-716

Smith SL, MacDonald DD, Keenleyside KA, Ingersoll CG, Field J (1996) A preliminary evaluation of sediment quality assessment values for freshwater ecosystems. J Great Lakes Res 22:624-638 
Snedecor GW, Cochran WG (1982) Statistical methods, 7th ed. Iowa State University Press, Ames, IA

SAS Institute (1994) SAS ${ }^{*}$ user's guide: statistics, version 5. Cary, NC Steingraeber MT, Wiener JG (1995) Bioassessment of contaminant transport and distribution in aquatic ecosystems by chemical analysis of burrowing mayflies (Hexagenia). Reg Riv Res Manage 11:201-209

Swartz RC, Di Toro DM (1997) Sediments as complex mixtures: an overview of methods to assess ecotoxicological significance. In: Ingersoll CG, Dillion T, Biddinger GR (eds) Ecological risk assessment of contaminated sediment. SETAC Press, Pensacola, FL, pp 255-269

Tomasovic MJ, Dwyer FJ, Greer IE, Ingersoll CG (1995) Recovery of known-age Hyalella azteca (Amphipoda) from sediment toxicity tests. Environ Toxicol Chem 14:1177-1180

United States Environmental Protection Agency (US EPA) (1994)
Methods for measuring the toxicity and bioaccumulation of sediment-associated contaminants with freshwater invertebrates. EPA/600/R-94/024, Duluth, MN

Wiener JG, Jackson GA, May TW, Cole BP (1984) Longitudinal distribution of trace elements ( $\mathrm{As}, \mathrm{Cd}, \mathrm{Cr}, \mathrm{Hg}, \mathrm{Pb}$, and $\mathrm{Se}$ ) in fishes and sediments in the upper Mississippi River. In: Wiener JG, Anderson RV, McConville DR (eds) Contaminants in the upper Mississippi River. Butterworth Publ., Boston, MA, pp $139-170$

Winger PV, Lasier PJ (1998) Toxicity of sediment collected upriver and downriver of major cities along the lower Mississippi River. Arch Environ Contam Toxicol 35:213-217

Zumwalt DC, Dwyer FJ, Greer IE, Ingersoll CG (1994) A waterrenewal system that accurately delivers small volumes of water to exposure chambers. Environ Toxicol Chem 13:1311-1314 